\title{
Research on the Relationship between Physical Exercise, Body Image and Social Self-efficacy of College Students
}

\author{
Li Yuehui \\ College of Technology and Art \\ Jingdezhen Ceramics University \\ Jingdezhen, China \\ 245540216@qq.com
}

\author{
Yuan Yan \\ Foreign Language Institute \\ Jingdezhen Ceramics University \\ Jingdezhen, China
}

\author{
Wang Zhijie \\ College of Technology and Art \\ Jingdezhen Ceramics University \\ Jingdezhen, China
}

\begin{abstract}
Self-efficacy theory is one of the most influential and persuasive motivational theories. Psychology researchers are glad about studying this theory, and social self-efficacy is a concept in Bandera's self-efficacy theory. Until now, there does not have a unified definition standard for the concept of body image. The explanation of body image in Zhang's Dictionary of Psychology is that the body image refers to "A subjective, comprehensive, and evaluative concept of one's own physical characteristics."[1]. Improving the college students' physical image and social self-efficacy are very important to their physical and mental health development. It will be also a good promotion for college students' untiring exercise and lifelong sports development.
\end{abstract}

Keywords-Physical exercise, physical image, social self efficacy

\section{STUDY PURPOSE}

Through the investigation of different training levels of college students and the current situation of body image and social self-efficacy, this paper reveals the relationship between physical exercise and physical intention and social selfefficacy, enriches the application value of psychological knowledge in social practice field, but also expands the function that physical exercising improves and enhances students' physical and mental health, enriches the content of students' Mental health education and carry out actively and beneficial practice.

The freshmen and sophomores are selected from eight colleges and universities in Jiangxi Province (Jingdezhen Ceramic Institute, Jinggangshan University, Gannan Normal University, Nanchang Aviation University, Jiangxi Normal University). (200 questionnaires were sent to each school, sampled in college units). TABLE I shows the gender and Grade distribution of the subjects.
TABLE I. GENDER AND GRADE DISTRIBUTION OF SUBJECTS IN DIFFERENT SECONDARY SCHOOLS

\begin{tabular}{lcccc}
\hline & \multicolumn{3}{c}{ Gender(N) } & \multicolumn{2}{c}{ Grade(N) } \\
\hline College & \multicolumn{2}{c}{ Male } & Female & Freshman Sophomore \\
\hline $\begin{array}{l}\text { Jingdezhen Ceramic } \\
\text { Institute }\end{array}$ & 118 & 81 & 104 & 95 \\
\hline Jinggangshan University & 98 & 45 & 73 & 70 \\
\hline $\begin{array}{l}\text { Gannan Normal } \\
\text { University }\end{array}$ & 52 & 118 & 93 & 77 \\
\hline $\begin{array}{l}\text { Nanchang Aviation } \\
\text { University }\end{array}$ & 76 & 65 & 77 & 64 \\
\hline Nanchang University & 138 & 61 & 94 & 105 \\
\hline
\end{tabular}

II. RESEARCH METHODS

\section{A. Measuring tools}

Social Self-Efficacy Scale: This study utilized the revision the scale of Perceived Social Self-efficacy (PSSE) by Meng Hui and Fan Jinyan in 2005 [2] which was developed by Smith and Betz in 1999

Multidimensional Body Image Questionnaire (MBSRQ): A multi-dimensional body image questionnaire (MBSRQ) edited by American psychologist Thomas F. Cash (2000) and revised by Taiwanese Wang Zhen song, in 2004 [3].

Self - made Physical Exercise Level Questionnaire: A selfdesigned questionnaire on the level of physical exercise was developed with reference to a similar questionnaire on the level of exercise. According to the need of the research, the questionnaire of physical exercise level was designed on the basis of similar exercise level questionnaire. In order to verify the validity of the questionnaire, the Author found 10 teachers who have long-term related study experience in teaching physical education and rectified their views. Nine of them found the questionnaire to be very suitable and one thought its relative suitable for the study. 


\section{B. Measurement methods}

Questionnaires were distributed in the college classes with the help of head teacher, and issued by author himself. Students were required to fill out questionnaires on the spot and on-site recycled. A total of 1308 valid questionnaires were collected, the effective rate was $81.8 \%$.

\section{Statistical processing of the data}

Use spss17.0 for windows statistical software to carry on the statistical processing to the survey data. The main statistical methods are: single-factor analysis of variance, multivariate analysis of variance, multiple regressions.

\section{SURVEY RESULTS AND ANALYSIS}

A. The statistical description of the variables of body image and social self-efficacy of all subjects

TABLE II shows the mean and standard deviation of the body image and self-efficacy of college students with different gender and grade.

TABLE II. DESCRIPTIVE STATISTICS $(M \pm S D)$ OF TEST VARIABLES FOR COLLEGE STUDENTS WITH DIFFERENT GENDER AND GRADE

\begin{tabular}{lccccc}
\hline & $\begin{array}{c}\text { social self- } \\
\text { efficacy }\end{array}$ & $\begin{array}{c}\text { appearance } \\
\text { evaluation }\end{array}$ & $\begin{array}{c}\text { external } \\
\text { concern }\end{array}$ & $\begin{array}{c}\text { health } \\
\text { evaluation }\end{array}$ & $\begin{array}{c}\text { health } \\
\text { care }\end{array}$ \\
\hline Freshman & $3.34 \pm 0.62$ & $3.01 \pm 0.51$ & $3.05 \pm 0.47$ & $3.40 \pm 0.63$ & $3.28 \pm 0.49$ \\
\hline Sophomore & $3.52 \pm 0.63$ & $3.16 \pm 0.55$ & $3.11 \pm 0.53$ & $3.52 \pm 0.64$ & $3.36 \pm 0.48$ \\
\hline Boys & $3.49 \pm 0.63$ & $3.17 \pm 0.54$ & $3.03 \pm 0.50$ & $3.52 \pm 0.63$ & $3.33 \pm 0.47$ \\
\hline Girls & $3.35 \pm 0.62$ & $2.97 \pm 0.50$ & $3.12 \pm 0.49$ & $3.39 \pm 0.63$ & $3.3 \pm 0.51$ \\
\hline \multicolumn{5}{r}{} \\
& & & & & (Note:*P<0.05*** $<0.01 ; * * * \mathrm{p}<0.001)$
\end{tabular}

B. Social self-efficacy, body image of the gender and gender differences in grade analysis

TABLE III shows the results of the score difference analysis of the four dimensions of social self-efficacy and body image in different gender and grade subjects.

TABLE III. DIFFERENT GENDER, GRADE DIFFERENCES IN TEST VARIABLES OF THE STUDENTS

\begin{tabular}{|c|c|c|c|c|c|c|}
\hline & Dependent variable & Type III & $\mathrm{df}$ & $\begin{array}{c}\text { Mean } \\
\text { square }\end{array}$ & $\mathrm{F}$ & $\mathrm{P}$ \\
\hline \multirow[t]{5}{*}{ Grade } & appearance evaluation & 7.187 & 1 & 7.187 & $26.638 * * *$ & 0.000 \\
\hline & external concern & 1.428 & 1 & 1.428 & $5.804 *$ & 0.016 \\
\hline & health evaluation & 4.322 & 1 & 4.322 & $10.872^{* * *}$ & 0.001 \\
\hline & health care & 2.17 & 1 & 2.17 & $9.127 * *$ & 0.003 \\
\hline & Social self-efficacy & 9.524 & 1 & 9.524 & $24.66^{* * *}$ & 0.000 \\
\hline \multirow[t]{4}{*}{ Gender } & appearance evaluation & 13.039 & 1 & 13.039 & $48.328 * * *$ & 0.000 \\
\hline & external concern & 2.585 & 1 & 2.585 & $10.506^{* * *}$ & 0.001 \\
\hline & health evaluation & 5.545 & 1 & 5.545 & $13.947 * * *$ & 0.000 \\
\hline & health care & 0.26 & 1 & 0.26 & 1.092 & 0.296 \\
\hline \multirow[t]{3}{*}{$\begin{array}{l}\text { Grade * } \\
\text { Gender }\end{array}$} & appearance evaluation & 0.26 & 1 & 0.26 & 0.963 & 0.327 \\
\hline & external concern & 0.061 & 1 & 0.061 & 0.248 & 0.618 \\
\hline & health evaluation & 0.409 & 1 & 0.409 & 1.028 & 0.311 \\
\hline
\end{tabular}

Multivariate analysis of variance (ANOVA) showed that grades had a significant effect on social self-efficacy, external concern, appearance evaluation, health evaluation and health care.

Gender scored significant effect in the appearance of evaluation, the appearance of concern, health evaluation, and social self-efficacy but there is no significant effect in health concerns. The interaction between grade and gender is not significant.

\section{The variables statistical description of college students' social self-efficacy and physical image in different exercising levels}

TABLE IV shows the average and standard deviation of social self-efficacy and body image of college students with different exercise levels. In this study, exercise frequency per week, exercise length each time, indefatigable exercise time were used as an physical exercise level index .exercise frequency per week is divided into occasional, 1-2 times, more than 3 times. Exercise length each time is divided into 30 minutes, 30-60 minutes, 1 hour or more. Indefatigable exercise time is divided into 3 months, 3-6 months, 6-12 months, more than a year.

TABLE IV. STATISTICAL DESCRIPTION OF TEST VARIABLES OF DIFFERENT EXERCISE LEVELS FOR COLLEGE STUDENTS $(\mathrm{M} \pm \mathrm{SD})$

\begin{tabular}{ccccc}
\hline \multicolumn{2}{c}{$\begin{array}{c}\text { weekly exercise } \\
\text { frequency }\end{array}$} & $\begin{array}{c}\text { exercise } \\
\text { times }\end{array}$ & $\begin{array}{c}\text { exercise } \\
\text { length/times }\end{array}$ \\
\hline Occasional & $1-2$ times & $>3$ times & 3 months & $3-6$ months \\
\hline $2.96 \pm 0.47$ & $3.04 \pm 0.51$ & $3.25 \pm 0.58$ & $2.97 \pm 0.48$ & $3.12 \pm 0.54$ \\
\hline $3.10 \pm 0.51$ & $3.06 \pm 0.49$ & $3.07 \pm 0.51$ & $3.11 \pm 0.49$ & $3.05 \pm 0.51$ \\
\hline $3.32 \pm 0.58$ & $3.39 \pm 0.63$ & $3.67 \pm 0.63$ & $3.32 \pm 0.61$ & $3.49 \pm 0.61$ \\
\hline $3.15 \pm 0.47$ & $3.30 \pm 0.47$ & $3.49 \pm 0.50$ & $3.19 \pm 0.48$ & $3.43 \pm 0.45$ \\
\hline $6-12$ months & $>1$ year & 30 minutes & $30-60$ minutes & $>1$ hour \\
\hline $3.11 \pm 0.47$ & $3.28 \pm 0.60$ & $3.00 \pm 0.47$ & $3.08 \pm 0.54$ & $3.32 \pm 0.65$ \\
\hline $2.97 \pm 0.46$ & $3.05 \pm 0.46$ & $3.12 \pm 0.49$ & $2.98 \pm 0.51$ & $3.16 \pm 0.45$ \\
\hline $3.48 \pm 0.60$ & $3.76 \pm 0.63$ & $3.34 \pm 0.62$ & $3.52 \pm 0.61$ & $3.68 \pm 0.67$ \\
\hline $3.30 \pm 0.50$ & $3.52 \pm 0.45$ & $3.20 \pm 0.50$ & $3.36 \pm 0.45$ & $3.55 \pm 0.45$ \\
\hline 1. Appearance evaluation 2. external & & &
\end{tabular}

\section{Variables difference of college students' social self-}

efficacy and physical image in different exercise levels

TABLE $V$ results show that the exercise frequency per week have a significant main effect on appearance evaluation, health evaluation and health care. Exercise length each time has a significant main effect on external concern and social self-efficacy. Indefatigable exercise time have a significant main effect on appearance evaluation, health evaluation, health care and social self-efficacy. Exercise frequency per week, Exercise length each time and indefatigable exercise time are interacting significantly. [4] 
TABLE V. VARIANCE ANALYSIS OF TEST VARIABLES OF COLLEGE STUDENTS IN DIFFERENT EXERCISE LEVELS

\begin{tabular}{|c|c|c|c|c|c|c|}
\hline & $\begin{array}{l}\text { Dependent } \\
\text { variable }\end{array}$ & $\begin{array}{c}\text { Type III } \\
\text { squared } \\
\text { sum }\end{array}$ & $\mathrm{df}$ & $\begin{array}{l}\text { Mean } \\
\text { square }\end{array}$ & $\mathrm{F}$ & $P$ \\
\hline \multirow[t]{5}{*}{$\begin{array}{l}\text { Weekly } \\
\text { exercise } \\
\text { frequency }\end{array}$} & $\begin{array}{l}\text { appearance } \\
\text { evaluation }\end{array}$ & 3.559 & 2 & 1.779 & $6.793 * *$ & 0.001 \\
\hline & external concern & 0.744 & 2 & 0.372 & 1.579 & 0.207 \\
\hline & health evaluation & 3.621 & 2 & 1.811 & $4.934 * *$ & 0.007 \\
\hline & health care & 4.747 & 2 & 2.374 & $11.385^{*}$ & 0.000 \\
\hline & $\begin{array}{l}\text { social self- } \\
\text { efficacy }\end{array}$ & 1.354 & 2 & 0.677 & 1.949 & 0.143 \\
\hline \multirow[t]{5}{*}{$\begin{array}{l}\text { exercise } \\
\text { length/ } \\
\text { times }\end{array}$} & $\begin{array}{l}\text { appearance } \\
\text { evaluation }\end{array}$ & 0.179 & 2 & 0.089 & 0.341 & 0.711 \\
\hline & external concern & 3.179 & 2 & 1.589 & $6.748 * *$ & 0.001 \\
\hline & health evaluation & 0.927 & 2 & 0.463 & 1.263 & 0.283 \\
\hline & health care & 0.562 & 2 & 0.281 & 1.348 & 0.26 \\
\hline & $\begin{array}{l}\text { social self- } \\
\text { efficacy }\end{array}$ & 4.841 & 2 & 2.421 & $6.97^{* * *}$ & 0.001 \\
\hline \multirow[t]{4}{*}{$\begin{array}{l}\text { exercise } \\
\text { times }\end{array}$} & $\begin{array}{l}\text { appearance } \\
\text { evaluation }\end{array}$ & 6.333 & 3 & 2.111 & $8.059 * *$ & 0.000 \\
\hline & external concern & 0.906 & 3 & 0.302 & 1.282 & 0.279 \\
\hline & health evaluation & 13.034 & 3 & 4.345 & $11.838 *$ & 0.000 \\
\hline & health care & 3.958 & 3 & 1.319 & $6.329 * *$ & 0.000 \\
\hline
\end{tabular}

In order to examine the difference effect on different dimensions of social self-efficacy and body image in different exercise levels, the exercise frequency per week, exercise length each time, indefatigable exercise time were compared in multiple mean. TABLE VI shows the multiple comparison results of different exercise frequency per week with appearance evaluation, health evaluation, health concerns.

The results show that in the appearance of evaluation, the exercise frequency per week at more than 3 times is significantly higher than the occasional and 1-2 times.

In the health evaluation and health concerns, the exercise frequency per week at more than 3 times is significantly higher than the occasional and 1-2 times, while 1-2 times is significantly higher than the occasional exercise.
TABLE VI. MULTIPLE COMPARISONS OF DIFFERENT EXERCISE FREQUENCY PER WEEKS

\begin{tabular}{|c|c|c|c|c|}
\hline $\begin{array}{l}\text { Dependent } \\
\text { variable }\end{array}$ & $\begin{array}{l}\text { (I)Weekly } \\
\text { exercise } \\
\text { frequency }\end{array}$ & $\begin{array}{l}\text { (J)Weekly } \\
\text { exercise } \\
\text { frequency }\end{array}$ & $\begin{array}{l}\text { (I-J)Mean } \\
\text { difference }\end{array}$ & $P$ \\
\hline \multirow{6}{*}{$\begin{array}{l}\text { appearance } \\
\text { evaluation }\end{array}$} & \multirow[t]{2}{*}{ occasional } & 1-2times & $-.0781 *$ & 0.027 \\
\hline & & $>3$ times & $-.2886^{*}$ & 0.000 \\
\hline & \multirow[t]{2}{*}{ 1-2times } & occasional & $.0781^{*}$ & 0.027 \\
\hline & & $>3$ times & $-.2104 *$ & 0.000 \\
\hline & \multirow[t]{2}{*}{$>3$ times } & occasional & $.2886^{*}$ & 0.000 \\
\hline & & 1-2times & $.2104^{*}$ & 0.000 \\
\hline \multirow{6}{*}{$\begin{array}{l}\text { health } \\
\text { evaluation }\end{array}$} & \multirow[t]{2}{*}{ occasional } & 1-2times & -0.0657 & 0.117 \\
\hline & & $>3$ times & $-.3464 *$ & 0.000 \\
\hline & \multirow[t]{2}{*}{ 1-2 times } & occasional & 0.0657 & 0.117 \\
\hline & & $>3$ times & $-.2807 *$ & 0.000 \\
\hline & \multirow[t]{2}{*}{$>3$ times } & occasional & $.3464 *$ & 0.000 \\
\hline & & 1-2times & $.2807^{*}$ & 0.000 \\
\hline \multirow[t]{6}{*}{ health concerns } & \multirow[t]{2}{*}{ occasional } & 1-2times & $-.1484^{*}$ & 0.000 \\
\hline & & $>3$ times & $-.3346^{*}$ & 0.000 \\
\hline & \multirow[t]{2}{*}{ 1-2 times } & occasional & $.1484 *$ & 0.000 \\
\hline & & $>3$ times & $-.1862 *$ & 0.000 \\
\hline & \multirow[t]{2}{*}{$>3$ times } & occasional & $.3346^{*}$ & 0.000 \\
\hline & & 1-2times & $.1862 *$ & 0.000 \\
\hline
\end{tabular}

TABLE VII shows the results of multiple comparisons of time-of-activity with appearance concern and social-selfefficacy. The results show that for the variable of appearance concerns, the length of activity time at more than 1 hour is significantly greater than at 30-60 minutes. And 30 to 60 minutes in significantly less than in 30 minutes. For the social self-efficacy variables, 1 hour or more is significantly greater than 30-60 minutes, 30 minutes; 30-60 minutes is significantly greater than 30 minutes.

TABLE VII. MULTIPLE COMPARISONS OF DIFFERENT LENGTH ACTIVITY TIMES

\begin{tabular}{lllll}
\hline $\begin{array}{l}\text { Dependent } \\
\text { variable }\end{array}$ & $\begin{array}{l}\text { (I)exercise } \\
\text { length/times }\end{array}$ & $\begin{array}{l}\text { (J)exercise } \\
\text { length/times }\end{array}$ & $\begin{array}{l}\text { (I-J)Mean } \\
\text { difference }\end{array}$ & $P$ \\
\hline $\begin{array}{l}\text { appearance } \\
\text { concerns }\end{array}$ & 30 minutes & $30-60$ minutes & $.1440^{*}$ & 0.000 \\
& \multirow{2}{*}{$30-60$ minutes } & 30 minutes & $-.1440^{*}$ & 0.000 \\
& & $>1$ hour & $-.1780^{*}$ & 0.000 \\
& & 30 minutes & 0.034 & 0.4 \\
social self - & \multirow{2}{*}{30 minutes } & $30-60$ minutes & $-.1925^{*}$ & 0.000 \\
efficacy & & $>1$ hour & $-.5230^{*}$ & 0.000 \\
& \multirow{2}{*}{$30-60$ minutes } & 30 minutes & $.1925^{*}$ & 0.000 \\
& & $>1$ hour & $-.3305^{*}$ & 0.000 \\
& & 30 minutes & $.5230^{*}$ & 0.000 \\
& & $30-60$ minutes & $.3305^{*}$ & 0.000 \\
\hline
\end{tabular}

E. The Relationship between Physical Exercise and College Students' Body Image and Social Self - efficacy

1) The correlation matrix and the mean standard deviation of the total sample of college students 
The results of correlation analysis are shown in Table VIII.Except for the low correlation between appearance attention and exercise frequency per week and exercise length each time. Other variables have significant correlations between body image and social self-efficacy,

The correlation between physical exercise and body image and social self-efficacy with different psychological significance, which can be further analyzed by multiple regression analysis. [5]

TABLE VIII. CORRELATION MATRIX FOR EACH SAMPLE

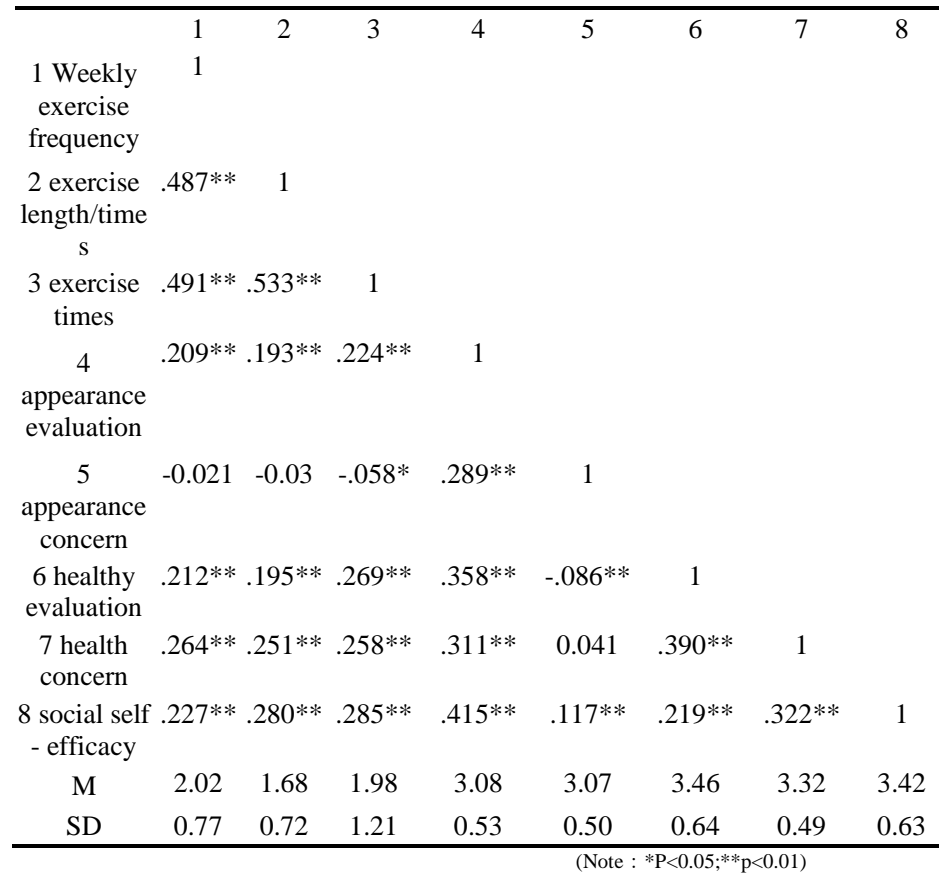

2) The relationship bet een physical exercise variables and social self-efficacy, physical image.

Appearance evaluation, healthy evaluation, health concern, social self-efficacy were considered as the dependent variable, physical exercise three dimensions were regarded as independent variables for stepwise regression, in this way exploring the influence of physical exercise on college students' body image, social self - efficacy. TABLE IX with social self-efficacy as the dependent variable, persevering exercise time, exercises length each time, exercise frequency per week as independent variables for stepwise regression. The model adjusted determination factor of 0.105 , which can explain that $10.5 \%$ of the total variance of social self-efficacy for the test result of model $F$ is significant $(p=0.000)$. By listing the regression coefficients in the model, we can see that the relative role of persevering exercise time, exercise length each time, exercise frequency per week as independent variables and social self-efficacy dependent variables.

TABLE $X$, shows that the regression coefficient of persevering exercise time is 0.167 , the regression coefficient of the exercise length each time is 0.157 , and the regression coefficient of weekly exercise frequency is 0.069 . It can be seen, the persevering exercise time is of the greatest impact on social self-efficacy.
TABLE IX. GRADUAL REGRESSION OF SOCIAL SELF-EFFICACY

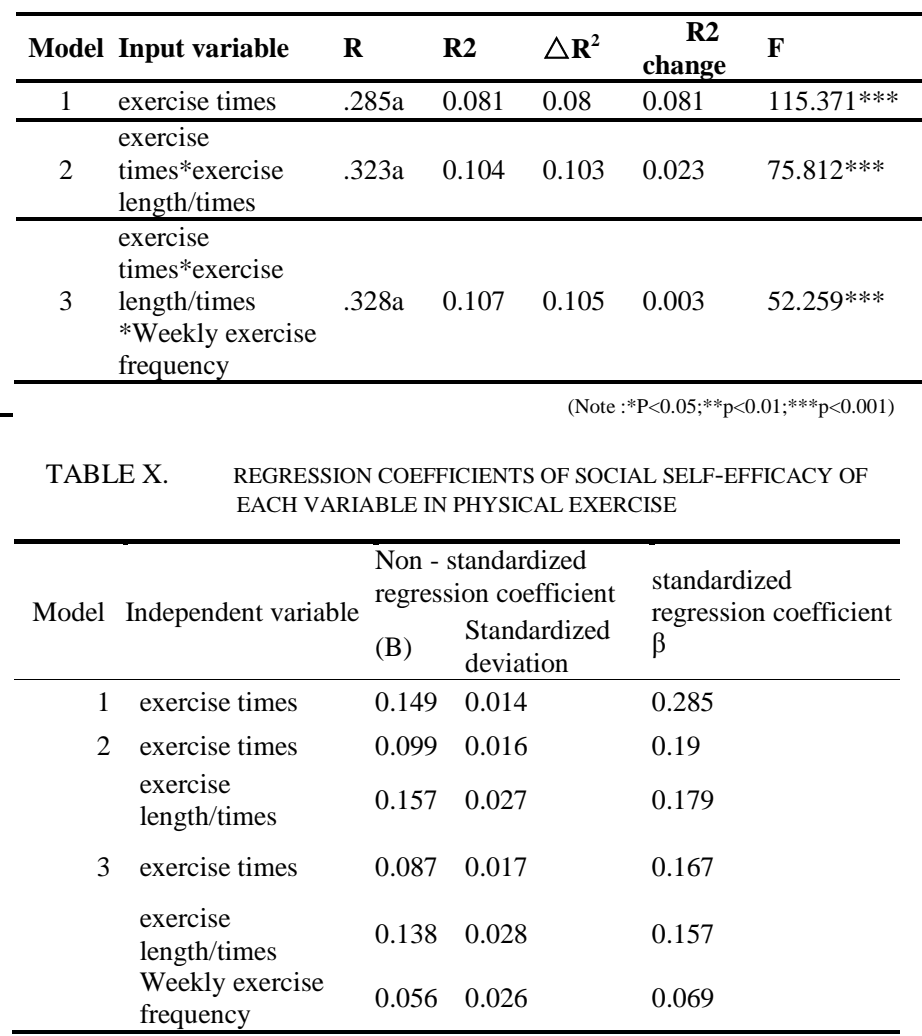

TABLE XI, with external evaluation as the dependent variable, unremitting exercise time, weekly exercise frequency and exercise length each time as the independent variable for stepwise regression model, the model adjustment coefficient of 0.064 , which can explain that the appearance evaluation of the total variance is $6.4 \%$ for the test result of model $F$ is significant $(\mathrm{p}=0.000)$. By listing the regression coefficient of the model, we can see that the relative role of persevering exercise time, exercise length each time, exercise frequency per week as independent variables and external evaluation dependent variables.

TABLE XII, shows that the regression coefficient of unremitting exercise time is 0.133 , the regression coefficient of weekly exercise frequency is 0.111 , and the regression coefficient of exercise length each time is 0.068 . It can be seen, unremitting exercise time have most influential on the appearance evaluation, followed by weekly exercise frequency, exercise length each time.

TABLE XI. STEPWISE REGRESSION OF APPEARANCE EVALUATION

\begin{tabular}{rllllll}
\hline Model & Input variable & $\mathbf{R}$ & $\mathbf{R 2}$ & $\Delta \mathbf{R}^{2}$ & $\begin{array}{l}\text { R2 } \\
\text { change }\end{array}$ & $\mathbf{F}$ \\
\hline 1 & exercise times & $.224 \mathrm{a}$ & 0.05 & 0.05 & 0.05 & $\begin{array}{l}69.101^{* *} \\
*\end{array}$ \\
\hline $\begin{array}{l}\text { exercise times } \\
2\end{array}$ & $\begin{array}{l}\text { *weekly exercise .252a } \\
\text { frequency }\end{array}$ & 0.063 & 0.062 & 0.013 & $\begin{array}{l}44.071^{* *} \\
*\end{array}$ \\
\hline $\begin{array}{l}\text { exercise times } \\
\text { *weekly exercise } \\
\text { frequency } \\
\text { *exercise } \\
\text { length/times }\end{array}$ & $.257 \mathrm{a}$ & 0.066 & 0.064 & 0.003 & $\begin{array}{l}30.863^{* *} \\
*\end{array}$ \\
\hline
\end{tabular}


TABLE XII. REGRESSION COEFFICIENTS OF PHYSICAL EXERCISE VARIABLES ON THE APPEARANCE EVALUATION

\begin{tabular}{|c|c|c|c|c|}
\hline \multirow{2}{*}{ Model } & \multirow{2}{*}{$\begin{array}{l}\text { Dependent } \\
\text { variable }\end{array}$} & \multicolumn{2}{|c|}{$\begin{array}{l}\text { Non- standardized } \\
\text { regression coefficient }\end{array}$} & \multirow{2}{*}{$\begin{array}{c}\text { Non- standardized } \\
\text { regression coefficient } \\
\beta\end{array}$} \\
\hline & & (B) & $\begin{array}{l}\text { Standard } \\
\text { deviation }\end{array}$ & \\
\hline 1 & exercise times & 0.099 & 0.012 & 0.224 \\
\hline \multirow[t]{2}{*}{2} & exercise times & 0.071 & 0.014 & 0.16 \\
\hline & $\begin{array}{l}\text { Weekly } \\
\text { exercise } \\
\text { frequency }\end{array}$ & 0.091 & 0.021 & 0.131 \\
\hline \multirow[t]{3}{*}{3} & exercise times & 0.059 & 0.015 & 0.133 \\
\hline & $\begin{array}{l}\text { Weekly } \\
\text { exercise } \\
\text { frequency }\end{array}$ & 0.077 & 0.022 & 0.111 \\
\hline & $\begin{array}{l}\text { exercise } \\
\text { length/times }\end{array}$ & 0.051 & 0.025 & 0.068 \\
\hline
\end{tabular}

TABLE XIII, with the e health valuation as the dependent variable, exercise time, weekly exercise frequency as independent variables for stepwise regression, the model adjustment coefficient of 0.079 , which can explain that the total variance of $7.9 \%$ for the test result of model $F$ is significant $(p=0.000)$. By listing the regression coefficient of the model, we can see that the relative role between detainable exercise time, weekly exercise frequency as independent variables and health evaluation dependent variables.

As shown in TABLE XIV, the regression coefficient of the indefatigable exercise time is 0.217 and the regression coefficient of weekly frequency exercise is 0.105 . It can be seen that the indefatigable exercise time has the greatest influence on health evaluation, followed by the weekly exercise frequency. [6]

TABLE XIII. STEPWISE REGRESSION OF HEALTH ASSESSMENT

\begin{tabular}{clccccc}
\hline Model & Input variable & $\mathbf{R}$ & $\mathbf{R} 2$ & $\triangle \mathbf{R}^{2}$ & R2change & $\mathbf{F}$ \\
\hline 1 & exercise times & $.269 \mathrm{a}$ & 0.072 & 0.071 & 0.072 & $101.591^{* * *}$ \\
\hline $\begin{array}{l}\text { exercise times } \\
\text { *weekly exercise } \\
\text { frequency }\end{array}$ & $.284 \mathrm{a}$ & 0.081 & 0.079 & 0.008 & $57.164^{* * *}$ \\
\hline
\end{tabular}

TABLE XIV. REGRESSION COEFFICIENTS OF HEALTH EXERCISE VARIABLES

\begin{tabular}{clccc}
\hline \multirow{2}{*}{ Model } & $\begin{array}{l}\text { Independent } \\
\text { variable }\end{array}$ & \multicolumn{2}{c}{$\begin{array}{c}\text { Non- standardized } \\
\text { regression coefficient }\end{array}$} & $\begin{array}{c}\text { Standardized } \\
\text { regression } \\
\text { coefficient } \\
\beta\end{array}$ \\
\cline { 3 - 4 } 2 & exercise times & 0.142 & 0.014 & $\begin{array}{c}\text { Standard } \\
\text { deviation }\end{array}$ \\
\hline 2 & $\begin{array}{l}\text { exercise times } \\
\text { Weekly exercise } \\
\text { frequency }\end{array}$ & 0.114 & 0.016 & 0.269 \\
\hline
\end{tabular}

TABLE XV, with health concern as the dependent variable, persevering exercise time, weekly exercise frequency, exercise length each time as the independent variable for stepwise regression model, the model adjusted coefficient of 0.098 , which can explain that the total health concern variance of
9.8\% for the test results for model $\mathrm{F}$ is significant $(\mathrm{P}=0.000)$. By listing the regression coefficient of the model, we can see that the relative importance role between persevering exercise time, weekly exercise frequency, exercise length each time as independent variables and health concerns dependent variables.

TABLE XVI, shows that the regression coefficient of persevering exercises time is 0.127 , the regression coefficient of weekly exercise frequency is 0.147 , and the regression coefficient of exercise length each time is 0.112 . It can be seen that weekly exercise frequency has the greatest influence on health evaluation, persevering exercise time exercise length each time are of the least impact. [7]

TABLE XV. GRADUAL REGRESSION OF HEALTH CONCERNS

\begin{tabular}{clccccc}
\hline Model & Input variable & $\mathrm{R}$ & $\mathrm{R} 2$ & $\mathrm{R}^{2}$ & $\mathrm{R} 2$ change & $\mathrm{F}$ \\
\hline 1 & $\begin{array}{l}\text { weekly exercise } \\
\text { frequency }\end{array}$ & $.264 \mathrm{a}$ & 0.07 & 0.069 & 0.07 & $\begin{array}{c}97.755^{* *} \\
*\end{array}$ \\
\hline 2 & $\begin{array}{l}\text { weekly exercise } \\
\text { frequency } \\
\text { *exercise times }\end{array}$ & $.303 \mathrm{a}$ & 0.092 & 0.09 & 0.022 & $\begin{array}{c}65.743^{* *} \\
*\end{array}$ \\
\hline
\end{tabular}

(Note :*P<0.05;**p $<0.01 ; * * * \mathrm{p}<0.001)$

TABLE XVI. THE REgRESSION COEFFICIENT OF PHYSICAL ACTIVITY VARIABLES ON HEALTH EVALUATION

\begin{tabular}{|c|c|c|c|c|}
\hline \multirow{2}{*}{ Model } & \multirow{2}{*}{$\begin{array}{l}\text { Independent } \\
\text { variable }\end{array}$} & \multicolumn{2}{|c|}{$\begin{array}{l}\text { Non- standardized } \\
\text { regression coefficient }\end{array}$} & \multirow{2}{*}{$\begin{array}{c}\text { Standardized } \\
\text { Regression } \\
\text { Coefficient } \beta\end{array}$} \\
\hline & & (B) & $\begin{array}{l}\text { Standard } \\
\text { deviation }\end{array}$ & \\
\hline 1 & $\begin{array}{l}\text { weekly exercise } \\
\text { frequency }\end{array}$ & 0.168 & 0.017 & 0.264 \\
\hline \multirow[t]{2}{*}{2} & $\begin{array}{l}\text { weekly exercise } \\
\text { frequency }\end{array}$ & 0.115 & 0.019 & 0.181 \\
\hline & exercise times & 0.069 & 0.012 & 0.17 \\
\hline \multirow[t]{3}{*}{3} & $\begin{array}{l}\text { weekly exercise } \\
\text { frequency }\end{array}$ & 0.094 & 0.02 & 0.147 \\
\hline & exercise times & 0.051 & 0.013 & 0.127 \\
\hline & $\begin{array}{l}\text { exercise } \\
\text { length/times }\end{array}$ & 0.076 & 0.022 & 0.112 \\
\hline
\end{tabular}

\section{CONCLUSION}

1. The scores of college students' body image and social self-efficacy have significant differences in gender and grade.

2. The different effects of physical exercise on body image and social self - efficacy are different. Long-term persevering physical exercise is of a better role in promoting on students' psychological development.

\section{REFERENCES}

[1] Zhang Chunxing. Zhang psychological dictionary [M]. Shanghai; Shanghai Dictionary Publishing House, 1991, P320.

[2] MENG Hui, FAN Jin-Yan, LIU Jing.Objective Orientation and Adaptation: Mediating Role of Social Self-Efficacy [J] .Psychological Development and Education, 2007, (1): 54-58.

[3] WANG Zheng-song, WANG Jian-xing.Research on Revision of Multidimensional Self-relation Questionnaire [J] .Taiwan Journal of Exercise, 2004, (5): 101-125. 
[4] .Zhang Lei,Sun Xuemei. Effects of Physical Exercise on Physical Self esteem and General Self - efficacy of College Students[J] .Tianjin Institute of Physical Education, 2009 (2).

[5] Wu Xujin,Yang Bin. Effects of Body Image and Self - efficacy on Female College Students' Exercise Behavior [J]. Journal of Tianjin Institute of Physical Education, 2006 (21) 4.

[6] Liu haiyan. Effects of Different Time and Intensity Aerobics Exercises on Self-efficacy and Mental Health of Female College Students[J]. Journal of Xi'an Institute of Physical Education, 2007.1.1. (24).

[7] Liu Guifang. The College Students' Physical Exercise and Sense of Social Self - efficacy [D]. Henan University, 2009. 